\title{
Issues of provisions in the Specification of the Essential Terms of Contract (SIWZ) in tenders for realization of forestry works
}

\author{
Urszula Bluszkowska, Tomasz Nurek 凶
}

Warsaw University of Life Sciences - SGGW, Faculty of Production Engineering, Department of Agricultural and Forestry Machines, Nowoursynowska 164, 02-787 Warsaw, Poland, phone: +48 22 5934513, e-mail: tomasz_nurek@sggw.pl

\begin{abstract}
The aim of the work was to analyse the provisions included in the Specifications of the Essential Terms of Contract in tenders for forestry works. The subject of the analysis was tender documentation of a selected Regional Directorate of State Forests. An attention was given to a number of inconsistencies, and non-specific and unjustified requirements. The presence of significant differences in the manner of defining requirements in the examined forest districts was emphasised. In opinion of the authors, the differences observed are unjustified and without any doubt impede the creation of tender documentation by representatives of forestry work companies. The summary of the analysis consists of, among others, a few guidelines on the manner of defining the requirements for forestry work companies and the need to unify the SIWZ provisions at the level of Regional Directorate of State Forests.
\end{abstract}

\section{KeY WORDS}

realization of forestry works, forestry work companies, Specification of the Essential Terms of Contract (SIWZ), tender for forestry work

\section{INTRODUCTION}

The changes that occurred in the Polish economy in 1980s and 1990s were also reflected in the manner of operation of the State Forest Company 'Lasy Państwowe'. As a result of the communism system collapse and changes in the market environment, the State Forests have implemented activities aimed at increasing the economic efficiency of the forest districts (Dawidziuk et al. 2014). The changes included, among others, an increased participation of the private sector in the State Forest economy and a development of legal regulations to form the free market, on one hand, and on the other, to maintain the State Treasury's control over the State Forests (Kocel 2010). The most crucial element of these transformations was a decrease in the number of the staff employed by the State Forest that fell by $78.72 \%$ (91,726 persons) between 1989 and 2011, including 78,683 workers who were let go (Kocel 2013). This was achieved by commissioning a great part of forest works to private companies. The primary benefit stemming from the engagement of the private sector was a significant decrease in cost of different works. 
The cooperation between forest districts and the private sector is based on the Public Procurement Law (Obwieszczenie 2015). Every economic task realized by external entities must be subject to a legally-defined tender procedure. This is realized based on the tender documentation, i.e. Specification of the Essential Terms of Contract drawn up by the employees of the forest districts. This documentation, apart from the detailed description of tasks to be realized, also contains a list of requirements that has to be met by all potential contractors. The above-mentioned requirements may be divided into four groups:

- knowledge and experience,

- availability of technical means,

- manpower,

- economical and financial situation.

These requirements are indisputably important and necessary throughout the tender procedure. This is because it is impossible to imagine signing a contract for the realization of expensive works without checking the other party's capabilities and financial stability first (Kocel and Szewczykiewicz 2013).

However, a preliminary analysis of the tender documentation and numerous interviews with the companies rendering forestry services indicate certain problems related to drawing up the necessary tender documentation by the companies. This is because the forest districts may define the requirements to be met by the companies in a highly diverse way, which may differ even if they concern similar works. This state of play results in additional barriers faced by the companies when creating a tender offer. Additionally, such situation seems to be difficult to support or justify in the situation where, in fact, there is just a single Ordering Party, that is, State Forests. Inconsistent wording and requirements result in unnecessary barriers for the potential contractors when creating the tender documentation. This work presents the results of analysis of tender documentation of a selected organizational unit of the State Forests and it also aimed at providing guidelines for streamlining of the tender process.

\section{Aim and scope}

The aim of the research is to analyse the quality of provisions of the Essential Terms of Contract (SIWZ) in a selected Regional Directorate of the State Forests. The scope of the research covered the tender documentation related to forestry works performed in ca. a dozen forest districts under the Directorate in question. The result of the research provided a number of recommendations on the manner of determining the requirements for potential contractors.

\section{MAterial AND MEthods}

The analysis was based on the tender documentation selected regional management of State Forests. The details include the Terms of Reference materials for all 17 forest districts, included in the analyzed management. Each document contains a full, detailed description of the requirements for all economic tasks planned for implementation in a given year. The analysis of the tender documentation of a selected Regional Directorate of the State Forests revealed that an assessment of offers filed by the forestry companies was realized based on the requirements that were divided into five groups. According to the provisions of the Public Procurement Law, the Ordering Party may require the potential contractor to provide an evidence of:

1. having employees certified to perform given tasks, activities;

2. having the proper knowledge and experience;

3. having the proper technical capability;

4. having employees with required qualification to realize a given order;

5. being in a stable financial and economic situation.

The assessment of these five areas is based on documents provided by a potential contractor with the tender documentation. According to the rules in force, the forest districts may require the potential contractors to provide respective certifications. As proved by the review of documentation, the number and types of certifications required by the forest districts varied.

The tables below contain exemplary provisions that can be found in the SIWZ documents that confirm, in the author's opinion, a lack of coherence and unification of the requirements between different state forest districts under the same Regional Directorate of the State Forests. Due to the great amount of data available, only three areas were selected for analysis. In order to facilitate the analysis, the provisions were grouped according to the type of requirement. 
Table 1. Selected provisions in SIWZ documentation on required knowledge and experience

\begin{tabular}{|c|c|}
\hline No & $\begin{array}{l}\text { Provisions included in the Essential Terms } \\
\text { of Contract (SIWZ) }\end{array}$ \\
\hline 1 & $\begin{array}{l}\text {.. the contractor shall realize in a period of } 3 \text { years, at least one service of the forest management type, that must be } \\
\text { performed for a period of one calendar year and must be characterized by a given value }(2,600,000.00 \text { PLN gross })\end{array}$ \\
\hline 2 & $\begin{array}{l}\text {... the contractor shall realize in a period of the last } 2 \text { years two services of the forest management type. The services must be } \\
\text { similar in their complexity and scope of works to the subject of the tender procedure. These are complex works "within the } \\
\text { scope of forest growth and management, protection, acquisition of wood, which are realised during } 12 \text { subsequent months in } \\
\text { a typical forest". The value of these works should be } 1,500,000.00 \text { PLN gross }\end{array}$ \\
\hline 3 & $\begin{array}{l}\text {... the contractors must perform at least one service of the forest management type, and the works must include performance } \\
\text { of tasks related to: acquisition and logging of wood, forest protection, forest creation, fire protection, seed works, selection } \\
\text { and environmental protection, education and tourism, maintenance of forest roads, maintenance of waterways, meadow } \\
\text { cutting. The value of these works must be no less than } 75 \% \text { of the gross value given in the tender offer for the works planned }\end{array}$ \\
\hline
\end{tabular}

Table 2. Selected provisions in SIWZ documentation on having the required technical capability

\begin{tabular}{|c|c|}
\hline No & $\begin{array}{l}\text { Provisions included in the Essential Terms } \\
\text { of Contract (SIWZ) }\end{array}$ \\
\hline 1 & ... should have petrol chainsaws of professional class \\
\hline 2 & ... should have petrol chainsaws with rated power no less than 2 HP \\
\hline 3 & ... should have a multipurpose machine for wood acquisition that is to participate in the thinning works \\
\hline 4 & ... should have available a harvester or a different device suitable for crown thinning (early and late) \\
\hline 5 & $\begin{array}{l}\text {... the device must follow the designated operating routes with width of } 3.0 \mathrm{~m} \text { spaced by about } 20 \mathrm{~m} \text { without causing damage } \\
\text { to the trees growing along the route. Moving the wood from the cutting point to the operating route must be realized without } \\
\text { the said wood touching the ground" }\end{array}$ \\
\hline 6 & $\begin{array}{l}\text {... for log extraction, the contractor must have available a special articulated tractor able to realize the task in the semi- } \\
\text { suspended or self-loading method. Optional with an agricultural tractor with a device allowing for extraction in the semi- } \\
\text { suspended method. For extraction of logs and stack wood, must have an equipment unit consisting of an engine unit } \\
\text { aggregated with a device allowing for realization of task in the self-loading method. Additionally, the contractor must have } \\
\text { available one self-loading unit for wood extraction (forwarder type) }\end{array}$ \\
\hline 7 & $\begin{array}{l}\text {... unit for self-loading wood extraction must be characterized by capacity no lower than } 3.0 \mathrm{~m} 3 \mathrm{p}^{*} \text {. For extraction of logs the } \\
\text { contractor must have available articulated special machines of the skider, forwarder or klembank type, possibly agricultural } \\
\text { tractors with rated power above } 100 \mathrm{HP} \text { or with double-axle drive, equipped for a forestry work cabin, cable winch and } \\
\text { stacking shields }\end{array}$ \\
\hline 8 & $\begin{array}{l}\text {... the skider type extraction tractors must have capacity of minimum } 500 \mathrm{~m}^{3} / \mathrm{month} \text {. Device for self-loading extraction of } \\
\text { stack wood and logs (forwarder type or equivalent) minimum } 300 \mathrm{~m}^{3} / \mathrm{month}\end{array}$ \\
\hline 9 & ... for extraction of stack wood using self-loading method may be used a tractor aggregated with a Jar type trailer \\
\hline 10 & $\begin{array}{l}\text {... extraction of medium sized wood (length up to } 3.5 \mathrm{~m} \text { ) using the self-loading method. The composition of such unit must } \\
\text { include: engine unit, crane with a claw and a trailer/carriage onto which the material will be loaded (the requirement will } \\
\text { be met by proper number of forwarder devices or tractors aggregated with a trailer and a crane/claw powered by hydraulics } \\
\text { of the tractor). In case of extraction of logs, the contractor must have available at least one specialist unit (forwarder type) } \\
\text { capable of self-loading extraction of logs (length up to } 6.1 \mathrm{~m} \text { ), and medium sized material with minimal length of } 2.1 \mathrm{~m} \text {. The } \\
\text { operating range of the crane cannot be lower than } 8 \mathrm{~m} \text { and the maximum load-bearing capacity of the trailer should be no } \\
\text { lower than } 10 \text { tonnes }\end{array}$ \\
\hline
\end{tabular}

* Provisions identical to the original wording in SIWZ. 
Table 3. Selected provisions in SIWZ documentation on having employees certified to perform the order

\begin{tabular}{|c|c|}
\hline No & $\begin{array}{l}\text { Provisions included in the Essential Terms } \\
\text { of Contract (SIWZ) }\end{array}$ \\
\hline 1 & ... having available, in relation to extraction, persons qualified as lumberjacks-drivers certified to work with a petrol chainsaw \\
\hline 2 & $\begin{array}{l}\text {... to have valid medical examination allowing for work using a petrol chainsaw. Having a person qualified to work with } \\
\text { a polesaw }\end{array}$ \\
\hline 3 & $\begin{array}{l}\text {... requirement for a proper number of persons "qualified as lumberjacks / chainsaw operators certified to work with a petrol } \\
\text { saw }\end{array}$ \\
\hline 4 & $\begin{array}{l}\text {... having proper number of persons "qualified as lumberjacks / chainsaw operators" and meeting the requirements stemming } \\
\text { from an Ordinance of the Minister of Environment dated } 24 \text { August } 2006 \text {. Additionally, every lumberjack must be equipped } \\
\text { with a measuring tape and a diameter tape }\end{array}$ \\
\hline 5 & $\begin{array}{l}\text {... operators certified to operate multi-use machines, extraction tractors and aggregated devices or attached devices and } \\
\text { vehicles - agricultural tractors and specialist tractors adapted to forestry work" }\end{array}$ \\
\hline 6 & $\begin{array}{l}\text { required are persons certified to: } \\
\text { operate an agricultural tractor adapted for extraction of logs or a specialist tractor for extraction of logs, } \\
\text { operate specialist machine for extraction of short logs - forwarder (these persons must meet the requirements detailed in the } \\
\text { Technical Inspection Law) or a person certified to operate a tractor adapted for self-loading extraction of short logs, equipped } \\
\text { with a crane (such persons must be certified to operate a crane, category: mobile cranes) }\end{array}$ \\
\hline 7 & $\begin{array}{l}\text {.. "certified to operate an agricultural tractor indicated by the Contractor" } \\
\text {... "certified to operate a specialist tractor type klemband or skidder" } \\
\text {... "certified to operate specialist tractor cranes, forwarder type" }\end{array}$ \\
\hline 8 & $\begin{array}{l}\text {... should have persons qualified to work with chemical agents, who have finished a course authorizing them to use such } \\
\text { chemical agents }\end{array}$ \\
\hline 9 & ... have in the team a person qualified to work with chemical agents \\
\hline 10 & $\begin{array}{l}\text {... person with valid qualifications to work with chemical agents, who finished a course in accordance with provisions of the } \\
\text { Act on Protection of Plants with subsequent changes, dated } 18 \text { December } 2003\end{array}$ \\
\hline 11 & $\begin{array}{l}\text {... persons who finished a training on using plant protection product. Such persons must have a valid certification on finishing } \\
\text { such course in accordance with the Act on Protection of Plants (Journal of Laws: Dz.U. no 133, Item } 849 \text { with subsequent } \\
\text { changes from 2008) }\end{array}$ \\
\hline 12 & ... should have persons competent to use plant protection products in forestry work \\
\hline
\end{tabular}

\section{Analysis of Results of the Research}

The provisions defining the requirements concerning the knowledge and experience for work performance, are limited to evidencing the competence by providing the scope of works performed before participating in the tender and by determining their value. As displayed by the three examples in Table 1, both requirements can be formulated differently. One of the forest districts (position 1) provided a very general description of the works to be done by the potential contractor. The other two are much more specific as to the scope of the prior forestry works. However, when analysing these provisions, one can assume that the Ordering Party required the Contractor to be experienced in all the works he might encounter in the particular forest districts. In such a case, the wording "the forest management type" is sufficient, especially if the tender covers a large, diverse work package. An interesting issue is the requirement concerning the value of works performed in the past by the entity that enters the tender. Some of the analysed forest districts provide detailed value of works to be done by the potential contractor, and other districts define only the amount by a percentage of the total value of the tender. In the quoted example this value was $75 \%$ of the works covered by the tender. The second manner of defining the requirements seems more universal, and 
therefore simpler for the forestry service companies. It can be assumed that this manner of defining the value of prior works could be applied in all forest districts under a the given regional directorate. Another issue that needs consideration is whether it possible is to establish a clear and unified percentage for all forest districts that would be considered sufficient to evidence the required level of experience of a potential contractor.

Similar inconsistencies are visible in the provisions on the required technical capability of the entities entering the tender. The first two requirements quoted exemplify the problems with a proper definition of requirements concerning such basic work equipment as a petrol chainsaw. "Professional class" is not clear and different manufacturers attach the "professional" label to their chainsaws that may vary greatly in terms of technical specifications. The requirement concerning the rated power of a chainsaw is clear; however, it is worth consideration whether works such as delimbing could not be performed with a chainsaw of lower rated power as such chainsaws are usually lighter. The remaining provisions presented in Table 2 concern the requirements for multi-use machines and extraction equipment. Especially interesting is the requirement concerning the monthly capacity of machines (position 8 in Table 2). The quantity of wood extracted in a given month is determined by many factors. Some of them are related to the type, model, technical parameters of the extraction device but others are related to the terrain and organisational conditions. As many authors pointed out (Nurek T. 2007) a number of factors, for example, the size of tasks to be accomplished and their localization, are of key importance in this respect. In the light of these opinions, the requirement concerning monthly capability of extraction tractors is incomprehensible, and it is in fact impossible to determine such values without defining the terrain and organisational conditions. When analysing the information obtained, certain attention was also given to the "Jar type trailer" presented in item 9 in Table 2. It should be mentioned that "Jar" is in fact a product name of a trailer produced by one of the national equipment suppliers and not a designation of a type. The quoted requirement may be in fact illegal as it directly suggests the need for the potential contractors to have particular equipment available. The Ordering
Party probably meant a self-loading trailer for wood extraction aggregated with a universal tractor. Another controversial issue is the expression "equipped for a forestry work cabin". A requirement for a cabin that ensures safety of the operator is understandable. However, "forestry work cabin" is somehow unclear. The requirements on safety define the required strength and ergonomics. An operator's cabin on a moving vehicle should have the proper safety certificate - and such certificates make no distinction between different operating locations for the machine.

Another group of requirements under scrutiny referred to having employees certified to perform given tasks. The problem consists in the difficulty in defining the requirements to be meet by an operator of a chainsaw. This is evidenced by examples given in Table 3 (items nos. 1, 2 and 3). In the quoted provisions we find such expressions as "lumberjack / driver", "lumberjack chainsaw operator", "qualification for operating a pole saw". It is difficult to explain why the Ordering Parties used two different expressions to define a person operating a chainsaw; the requirement concerning a pole saw is also unclear. A person who formulated this requirement and included it in the tender documentation could have thought about a chainsaw with a cutting element is located at the end of a pole, however the Polish law does not foresee any special additional types of requirements for working with such devices. Upon completion of a training course for lumberjacks, operators of petrol chainsaws are given an authorisation for using all types of petrol chainsaws. The tender documentation drawn up by one of the forest districts under analysis directly requires a valid health certificate (Tab. 3, item 2). This requirement is especially vexing as it is difficult to imagine employing anyone for any position without the valid health certifications required for this position. While analysing the tender documentation, an attention was also given to the highly varied provisions and requirements for operators of different types of wheeled vehicles (Tab. 3). According to the regulations in force, a document required for operating tractors and slow-speed vehicles is a driving licence category T. For hydraulic cranes, which are used for timber harvesting by self-loading tractors or harvesters, the certification for near transport equipment (requirement of the Office of Technical Inspection - UDT) is required. It seems that these two requirements should satisfy the Order- 
ing Party's needs with regard to the potential operators of extraction equipment and harvesters. However, it should be mentioned that being certified, and being skilled and experienced in using a given piece of equipment are two different things. The latter may be proven by different certificates, for example, for harvester operators, or the amount of time of working at a given position. Another crucial thing is that the required documents are a driving licence and a crane operator licence, in legal sense.

Employing a staff properly certified for working with dangerous chemical substances is also of key importance, especially from the viewpoint of the environmental protection and regulations of the health and safety at work. Table 3 contains a number of exemplary provisions taken from the SIWZ documents. An interesting fact is that two of the quoted forest districts do not refer to any legal acts while formulating the tender requirements, whereas other districts refer to different legal basis.

\section{Conclusions AND discussion}

As proved in the above analysis, there are many provisions of the Essential Terms of Contract that raise justified questions and doubts. Formulating differing, sometimes not entirely logical and materially justified requirements seems unsubstantiated. When assessing the situation from the viewpoint of the forestry services, it should be stated that such situation makes the preparation of tender documentation more difficult and longer. The owner of a forestry service company, who wants to enter into tenders in a few forest districts, has to collect different documents, containing different information based on the request of the Ordering Party. The scope and diversity of forest-related works partly justify such a need, however, it seems that in most cases the tender documentation could be made simpler and unified. Is it justified that within one Regional Directorate of the State Forests the requirements for forestry service companies are so freely changed? The unification of the nomenclature and basic provisions would be a great benefit for both parties. From the viewpoint of the forest districts, such an undertaking would increase the clarity and quality of the documentations filed. Clear provisions and requirements are expected to assure the same level of clarity in the documents filed by the forestry service companies. The forestry service companies are also expected to gain significantly if these changes were introduced. If a part, at least, of the requirements to be met were formulated in the same manner, no matter the forest district, the requirements and documents provided by the forest companies would be the same. This would simplify the process of drawing up documents required by different forest districts, and shorten the time needed to prepare it, to a significant extent. Certain information referring to the equipment, employment, financial situation or other information that tend not to change very dynamically, could serve as a form of a database about the forest service companies. Such a database could be used according to specific needs expressed in various tenders in different forest districts.

The analysis presented above aimed at presenting inconsistencies and differences, and the variability of requirements for forestry service companies in the public tender procedures. The situation described above is a problem for companies that render services for the State Forests. The tender documentation is constantly subject to analyses performed by both, the forest districts and the forestry service companies. Both sides are willing to introduce those changes. The unification of the requirements set for the companies entering various tenders may-be very helpful in selecting the proper contractor, on one hand, and on the other hand, they may support a creation of healthy competition based on constant improvement of qualifications.

Based on the above analysis, indicating discrepancies, inconsistencies, and also a large span requirements of entrepreneurs in tenders for the construction of forestry you can draw the following conclusions:

- tender documents prepared by forest districts within a single regional directorates of state forests characterized by significant differences in the formulation of requirements for companies bidding,

- some of the records testify to the lack of proper preparation of preparing tender documents,

- efforts should be made to harmonize as much as possible within the Regional Directorate of State Forests requirements for contractors in tenders for construction work

- it is desirable to create a database accessible to the management of forest districts, which contains information about contractors. 


\section{References}

Dawidziuk J., Zajączkowski S., Wysocka-Fijorek E. 2014. Economic aspects in palnning. A panel of experts "development" forests and forest management as instruments of economic and social development of rural areas, Sękocin Stary, 2014.

Kocel J. 2010. Development of the forestry services sector in Poland. Folia Forestalia Polonica, Series A - Forestry, 52 (1), 44-53.

Kocel J. 2013. Forest companies in Poland (in Polish). Centrum Informacyjne Lasów Państwowych, Warszawa, 97-116.
Kocel J., Szewczykiewicz J. 2013. Utilisation of business information by private forest entrepreneurs (in Polish with English summary). Sylwan, 157 (2), 83-94.

Nurek T. 2007. The method of assessing the effectiveness of the machine logging in terms of forest Polish. Wydawnictwo SGGW, Warszawa, 89-105.

Obwieszczenie Marszałka Sejmu Rzeczypospolitej Polskiej z dnia 26 listopada 2015 r. w sprawie ogłoszenia jednolitego tekstu ustawy - Prawo zamówień publicznych. Dz.U., poz. 2164. 